\title{
PENGETAHUAN DAN MOTIVASI DENGAN SIKAP PERAWAT DALAM PEMENUHAN KEBUTUHAN SPIRITUAL PASIEN DI RUANG RAWAT INAP RSUD dr. H. CHASAN BOESOIRIE TERNATE
}

\begin{abstract}
Arsad Suni $^{*}$, Damir Umanailo ${ }^{*}$, Ruslan Dabi Dabi ${ }^{*}$
Abstract : One aspect of professional services in nursing is a matter of spiritual fulfillment, but in fact the spiritual needs of patients less attention by the nurses. This study aims to determine the related to the attitude of the nurse in meeting the spiritual needs of patients. Comparative research design using a cross sectional analytic study, samples were taken using a nonprobability sampling with purposive sampling, sample number 95 nurses working in the inpatient Medical-Surgical Hospital Dr. H. Chasan Boesoirie Ternate. Data collection using questionnaires to measure the level of knowledge, motivation and attitude of nurses in meeting the spiritual needs of patients. Data analysis using Chi-Square test to see the correlation between education, knowledge and motivation to nurse attitudes, whereas multivariate analysis is used to see the most dominant factors related to nurse attitudes. In this study, the results obtained by respondents who had a positive attitude as much as $36.8 \%$, a negative attitude as much as $63.2 \%$. Chi-Square test results with the attitude of educational factors $(p=0.007)$, knowledge $(p=0.003)$, motivation $(p=0.004)$. Multivariate analysis showed the most dominant factor is related to the attitude of education (Exp $(B)=5.704)$. It is concluded that there is a significant relationship between education, knowledge and motivation with the attitude of nurses in meeting the spiritual needs of patients in the inpatient Medical-Surgical Hospital Dr. H. Chasan Boesoirie Ternate. The higher the education nurses tend to be more positive attitude, while the lack of knowledge and low motivation of the nurses tend to be more negative the attitude in meeting the spiritual needs of patients. The dominant factor is related to the attitude of education. It is hoped that further enhance human resources related to quality nursing services in general and in particular in meeting the spiritual needs of patients through the application of holistic nursing care.
\end{abstract}

Key words : Spiritual Needs, Attitudes, Education, Knowledge, and Motivation.

\section{PENDAHULUAN}

Salah satu aspek pelayanan profesional dalam keperawatan adalah masalah pemenuhan kebutuhan spiritual. Hal ini menjadi penting karena ketika kondisi fisik seseorang terganggu maka ada kemungkinan mengalami perubahan emosi. Pada kondisi tersebut, aspek spiritual seseorang sangat diperlukan untuk mengatasi perubahan emosi tersebut. Hawari (2010), menyatakan bahwa keimanan pada Tuhan diyakini akan memudahkan seseorang untuk mengatasi perubahan emosional selama sakit.

Penelitian oleh Rahmat, I. pada tahun 2002, tentang keefektifan pemberian bimbingan spiritual Islami kepada klien terminal terhadap kecemasan dan motivasi hidup di RSU PKU Muhammadiyah Yogyakarta menyimpulkan bahwa pemberian bimbingan spiritual efektif untuk menurunkan kecemasan segera setelah diberikan bimbingan kepada klien yang mengalami penyakit terminal, tetapi setelah tidak dibimbing dalam dua minggu kecemasan klien terminal berangsur-angsur meningkat lagi. Selain itu pemberian bimbingan spiritual efektif meningkatkan motivasi hidup bagi klien terminal, baik tentang kesungguhan mencari nafkah, keinginan untuk meningkatkan kebutuhan-kebutuhan hidup maupun keajegan dalam bekerja.

Survey yang dilakukan oleh majalah Time dan CNN 1996, dan dikembangkan oleh (Larson, et. al, 2000) dikutip dalam Hawari tahun 2010, menyebutkan bahwa lebih dari 75 $\%$ responden menyatakan psikoterapi agama membawa hasil yang signifikan, dimana keyakinan mereka dengan berdoa dan berzikir kepada Tuhan Yang Maha Kuasa dapat membantu proses penyembuhan penyakit. Sementara itu dalam praktik sehari-hari (Lorson, et. al, 2000) menyatakan bahwa lebih dari $68 \%$ pasien menginginkan agar dokter memberikan terapi psikoreligius, doa dan dzikir. Dari survey ini menunjukkan bahwa sebenarnya pasien membutuhkan terapi keagamaan selain terapi dengan obat-obatan dan tindakan medis lainnya (Wright, 2000) dikutip dalam Hamid tahun 2009, mengatakan bahwa dalam memberikan asuhan keperawatan, perawat lebih cenderung memperhatikan aspek curent (pengobatan). Lebih lanjut Hamid mengemukakan bahwa perawat kurang memperhatikan aspek spiritual dalam perawatan karena perawat kurang 
memahami tentang aspek spiritual dan manfaatnya terhadap kesehatan serta penyembuhan penyakit pasien, selain itu kurangnya pengetahuan perawat tentang asuhan keperawatan spiritual pasien menjadi salah satu penyebab pemenuhan kebutuhan spiritual pasien kurang diperhatikan oleh perawat.

\section{Rumusan Masalah}

Berdasarkan pengamatan penulis selama ini di RSUD Dr. H. Chasan Boesoirie Ternate, khususnya di ruang rawat inap Medik-Bedah, kebutuhan spiritual ini hanya menjadi prioritas pada pasien dalam keadaan kritis, atau menjelang kematian, dan sebagian besar perawat tidak mendampingi pasien pada saat menjelang kematian/sakratul maut karena perawat sibuk melaksanakan tindakan-tindakan yang mengarah pada pengobatan pasien yaitu melakukan tindakan sesuai dengan instruksi dokter sehingga kebutuhan spiritual pasien sering terabaikan.

\section{Tujuan Penelitian}

Penelitian ini bertujuan untuk mengetahui hubungan pendidikan, pengetahuan dan motivasi dengan sikap perawat dalam pemenuhan kebutuhan spiritual pasien.

\section{METODE PENELITIAN}

\section{Lokasi dan Rancangan Penelitian}

Penelitian telah dilakukan di RSUD Dr. H. Chasan Boesoirie Ternate yang merupakan salah satu rumah sakit rujukan di Propinsi Maluku Utara. Jenis penelitian yang digunakan adalah analitik komparatif dengan metode Cross Sectional Study.

\section{Populasi dan Sampel}

Populasi adalah seluruh perawat yang bekerja di ruang rawat inap Medik-Bedah RSUD Dr. H.Chasan Boesoirie Ternate. Sampel sebanyak 95 orang yang dipilih secara Purposive Sampling yang telah memenuhi kriteria inklusi yaitu perawat yang bekerja di ruang rawat inap Medik-Bedah, dan perawat yang bersedia untuk diteliti dengan menandatangani informed consent penelitian.

\section{Metode Pengumpulan Data}

Pengumpulan data dilakukan oleh peneliti dengan menggunakan kuesioner yang diberikan kepada perawat sebagai responden dan kuesionernya diisi sendiri oleh responden setelah mendapat penjelasan dari peneliti. Data faktor pendidikan, pengetahuan, motivasi dan sikap perawat dalam pemenuhan kebutuhan spiritual pasien diukur dengan menggunakan kuesioner. Kuesioner dalam penelitian ini dibuat sendiri oleh peneliti berdasarkan buku sumber atau literatur yang digunakan dalam penelitian dan telah dilakukan uji validitas dan reliabilitas sebelum penelitian ini dilakukan.

\section{Analisis Data}

Data diolah dan dianalisis berdasarkan skala ukur dan tujuan penelitian dengan menggunakan perangkat lunak program komputerisasi dan disajikan dalam bentuk tabel. Untuk melihat hubungan faktor pendidikan, pengetahuan dan motivasi terhadap sikap perawat dalam pemenuhan kebutuhan spiritual pasien dengan menggunakan uji statistik Chi-Square, dengan nilai kemaknaan $\mathrm{p} \square 0,05$. Selain itu dilakukan uji analitik multivariat regresi logistik untuk melihat faktor yang paling dominan hubungannya terhadap sikap perawat.

\section{HASIL PENELITIAN}

\section{Karakteristik Sampel}

Tabel 1 memperlihatkan karakteristik perawat yang menjadi sampel dalam penelitian ini. Sebagian besar perawat berumur antara 2030 tahun, yaitu 54 orang $(56,8 \%)$ yang merupakan kelompok umur dewasa awal (early adulthood). Mayoritas perawat yang bekerja di ruang rawat inap Medik-Bedah RSUD. Dr. H. Chasan Boesoirie Ternate berjenis kelamin perempuan, yaitu 75 orang (78,9\%). Berdasarkan tingkat pendidikan sebagian besar perawat berpendidikan D III Keperawatan, yaitu 68 orang $(71,6 \%)$, sedangkan yang masih berpendidikan SPK sebanyak 21 orang $(22,1 \%)$, sementara yang berpendidikan Ners masih sangat sedikit, yaitu hanya 6 orang $(6,3 \%)$. Mayoritas perawat mempunyai masa kerja 1-5 tahun, yaitu 52 orang $(54,7 \%)$. Distribusi responden berdasarkan ruangan yang terbanyak adalah ruang Interna Pria dan Perawatan Bedah yaitu masing-masing 14 orang $(14,7 \%)$, sedangkan yang paling sedikit adalah Vip Bedah yaitu 9 orang $(9,5 \%)$. 
Tabel 1. Karakteristik responden berdasarkan umur, jenis kelamin, pendidikan, masa kerja dan ruangan perawatan.

\begin{tabular}{lcc}
\hline \multicolumn{1}{c}{ Karakteristik } & f & \% \\
\hline Umur & 54 & 56,8 \\
20-30 Tahun & 33 & 34,7 \\
31-40 Tahun & 8 & 8,4 \\
> 40 Tahun & & \\
\hline Jenis Kelamin & 20 & 21,1 \\
Laki-laki & 75 & 78,9 \\
Perempuan & & \\
Pendidikan & 21 & 22,1 \\
SPK & 68 & 71,6 \\
DIII Keperawatan & 6 & 6,3 \\
S1 Keperawatan (Ners) & & \\
Masa Kerja & 52 & 54,7 \\
1-5 Tahun & 18 & 18,9 \\
6-10 Tahun & 25 & 26,3 \\
10 Tahun & & \\
\hline Ruangan & 14 & 14,7 \\
Interna Pria & 12 & 12,6 \\
Interna Wanita & 10 & 10,5 \\
Pulmo & 10 & 10,5 \\
Neuro & 9 & 9,5 \\
Vip Bedah & 13 & 13,7 \\
Vip Interna & 14 & 14,7 \\
Perawatan Bedah & 13 & 13,7 \\
ICU/ICCU & 95 & 100 \\
\hline$\quad$ Total & & \\
\hline Suld & & \\
\hline
\end{tabular}

Sumber data primer Oktober 2013

\section{Analisis Bivariat}

Tabel 2 memperlihatkan bahwa dari 74 responden yang memiliki pendidikan tinggi, 41 orang $(55,4 \%)$ diantaranya memiliki sikap yang negatif dan 33 orang $(44,6 \%)$ yang memiliki sikap positif. Selanjutnya dari 21 responden yang berpendidikan Menengah, 19 orang $(90,5 \%)$ memiliki sikap negatif dan hanya 2 orang $(9,5 \%)$ yang memiliki sikap positif dalam pemenuhan kebutuhan spiritual pasien. Ditemukan ada hubungan yang bermakna antara pendidikan dengan sikap perawat dalam pemenuhan kebutuhan spiritual pasien $(\mathrm{p}<0.05)$.

Tabel 2. Hubungan pendidikan dengan sikap perawat dalam pemenuhan kebutuhan spiritual pasien

\begin{tabular}{|c|c|c|c|c|c|c|c|}
\hline \multirow{3}{*}{ Pendidikan } & \multicolumn{4}{|c|}{ Sikap } & \multirow{2}{*}{\multicolumn{2}{|c|}{ Jumlah }} & \multirow{3}{*}{$P$} \\
\hline & \multirow{2}{*}{$\frac{\text { Positif }}{\mathrm{f}}$} & \multicolumn{3}{|c|}{ Negatif } & & & \\
\hline & & $\%$ & $\mathrm{~F}$ & $\%$ & $\mathrm{n}$ & $\%$ & \\
\hline Tinggi & 33 & 44,6 & 41 & 55,4 & 74 & 100 & \\
\hline Menengah & 2 & 9,5 & 19 & 90,5 & 21 & 100 & 0,007 \\
\hline Jumlah & 35 & 36,8 & 60 & 63,2 & 95 & 100 & \\
\hline
\end{tabular}

Sumber data primer Oktober 2013

Tabel 3 menunjukkan bahwa, dari 45 responden yang memiliki pengetahuan baik, tidak semuanya memiliki sikap positif dalam pemenuhan kebutuhan spiritual pasien, yaitu terdapat 21 orang $(46,7 \%)$ diantaranya memiliki sikap negatif, dan dari 50 responden dengan pengetahuan kurang, sebagian besar yaitu sebanyak 39 orang (78\%) memiliki sikap yang negatif terhadap pemenuhan kebutuhan spiritual pasien. Ditemukan ada hubungan yang bermakna antara pengetahuan dengan 
sikap perawat dalam pemenuhan kebutuhan

spiritual pasien $(\mathrm{p}<0.05)$.

Tabel 3. Hubungan pengetahuan dengan sikap perawat dalam pemenuhan kebutuhan spiritual pasien

\begin{tabular}{|c|c|c|c|c|c|c|c|}
\hline \multirow{3}{*}{ Pengetahuan } & \multicolumn{4}{|c|}{ Sikap } & & & \multirow{3}{*}{$P$} \\
\hline & \multicolumn{2}{|c|}{ Positif } & \multicolumn{2}{|c|}{ Negatif } & \multicolumn{2}{|c|}{ Jumlah } & \\
\hline & f & $\%$ & $\mathbf{F}$ & $\%$ & $\mathbf{N}$ & $\%$ & \\
\hline Baik & 24 & 53,3 & 21 & 46,7 & 45 & 100 & \\
\hline Kurang & 11 & 22,0 & 39 & 78,0 & 50 & 100 & 0.003 \\
\hline Jumlah & 35 & 36,8 & 60 & 63,2 & 95 & 100 & \\
\hline
\end{tabular}

Sumber data primer Oktober 2013

Tabel 4 memperlihatkan bahwa dari 43 responden dengan motivasi yang tinggi, 23 orang $(53,5 \%)$ memiliki sikap positif dan 20 orang $(46,5 \%)$ memiliki sikap negatif dalam pemenuhan kebutuhan spiritual pasien, sementara sebanyak 52 responden dengan motivasi rendah, 12 orang $(23,1 \%)$ memiliki sikap yang positif dan 40 orang $(76,9 \%)$ yang memiliki sikap negatif dalam pemenuhan kebutuhan spiritual pasien. Ditemukan ada hubungan yang bermakna antara motivasi dengan sikap perawat dalam pemenuhan kebutuhan spiritual pasien $(\mathrm{p}<0.05)$.

Tabel 4. Hubungan motivasi dengan sikap perawat dalam pemenuhan kebutuhan spiritual pasien

\begin{tabular}{|c|c|c|c|c|c|c|c|}
\hline \multirow{3}{*}{ Motivasi } & \multicolumn{4}{|c|}{ Sikap } & \multirow{2}{*}{\multicolumn{2}{|c|}{ Jumlah }} & \multirow{3}{*}{$P$} \\
\hline & \multicolumn{2}{|c|}{ Positif } & \multicolumn{2}{|c|}{ Negatif } & & & \\
\hline & $\mathbf{f}$ & $\%$ & f & $\%$ & $\mathbf{N}$ & $\%$ & \\
\hline Tinggi & 23 & 53,5 & 20 & 46,5 & 43 & 100 & \multirow{3}{*}{0.00} \\
\hline Rendah & 12 & 23,1 & 40 & 76,9 & 52 & 100 & \\
\hline Jumlah & 35 & 36,8 & 60 & 63,2 & 95 & 100 & \\
\hline
\end{tabular}

Sumber data primer Oktober 2013

\section{Analisis Multivariat}

Tabel 5 diperlihatkan bahwa diantara tiga variabel yaitu pendidikan, pengetahuan dan motivasi, yang paling dominan hubungannya dengan sikap perawat adalah pendidikan, dimana memiliki nilai $\operatorname{Exp}(\mathrm{B})$ 5,704 , artinya responden yang memiliki pendidikan tinggi berpeluang 5,704 kali lebih bersikap positif dalam pemenuhan kebutuhan spiritual pasien dibanding responden yang memiliki pendidikan menengah.

Tabel 5. Hasil analisis regresi logistic faktor-faktor yang berhubungan dengan Sikap perawat dalam pemenuhan kebutuhan spiritual pasien

\begin{tabular}{lccccc}
\hline \multicolumn{1}{c}{ Variabel } & S.E. & Wald & df & Sig. & Exp(B) \\
\hline Pendidikan & 0,820 & 4,508 & 1 & 0,034 & 5,704 \\
Motivasi & 0,482 & 5,914 & 1 & 0,015 & 3,230 \\
Pengetahuan & 0,488 & 4,006 & 1 & 0,045 & 2,657 \\
\hline
\end{tabular}

Sumber : data primer Oktober 2013

\section{PEMBAHASAN}

\section{Pendidikan}

Pendidikan sangat mempengaruhi sikap perawat dalam pemenuhan kebutuhan spiritual pasien. (Siagian, 2011), menyatakan bahwa karyawan dengan pendidikan lebih tinggi memiliki kepuasan kerja yang tinggi dan cenderung bersikap positif karena dilandasi rasa aktualisasi atau pengakuan. Pendidikan tinggi umumnya membuat seseorang lebih mampu dan bersedia menerima tanggunga jawab. Dengan pendidikan tinggi, perawat akan lebih mampu menganalisis dan mengidentifikasi masalah pasien, yang kemudian secara rasional dapat mempertimbangkan intervensi keperawatan yang tepat untuk mengatasi masalah-masalah pasien (Barnadib, 1991) dikutip dalam Nursalam tahun 2011. 
Penelitian Ismail pada tahun 2012, di RSKD Makassar menyebutkan bahwa materi perawatan yang diperoleh selama pendidikan akan meningkatkan pemahaman perawat dalam perawatan spiritual. Pada penelitian ini terlihat bahwa dari 21 perawat yang memiliki pendidikan menengah 90,5\% diantaranya memiliki sikap negatif dalam pemenuhan kebutuhan spiritual pasien dan responden yang memiliki pendidikan tinggi berpeluang 5,704 kali lebih bersikap positif dalam pemenuhan kebutuhan spiritual pasien dibanding responden yang memiliki pendidikan menengah. Hal ini dapat diasumsikan bahwa perawat yang berpendidikan tinggi cenderung lebih bersikap positif dalam pemenuhan kebutuhan spiritual pasien dibanding perawat dengan tingkat pendidikan menengah, sehingga dapat dikatakan bahwa faktor pendidikan memiliki peranan penting dalam menentukan sikap perawat, khususnya dalam hal pemenuhan kebutuhan spiritual pasien.

\section{Pengetahuan}

Pengetahuan seseorang dipengaruhi oleh faktor internal dan eksternal. Faktor internal meliputi pendidikan, pekerjaan, umur, mental, minat dan tingkat intelegensi. Faktor eksternal mencakup lingkungan dan sosial budaya (Slameto, 2006)vdikutip dalam Wawan dan Dewi, tahun 2010.

Hasil penelitian Amelianus, M. pada tahun 2003 di RSUD Prof. DR. W.Z. Johannes Kupang yang membuktikan bahwa terdapat hubungan yang signifikan antara pengetahuan dan sikap perawat dalam pemenuhan kebutuhan spiritual pasien.

Hasil penelitian ini membuktikan bahwa dari 45 responden yang memiliki pengetahuan baik $53,3 \%$ memiliki sikap positif, dan dari 50 responden dengan pengetahuan kurang, sebagian besar yaitu 39 orang $(78 \%)$ memiliki sikap yang negatif dalam pemenuhan kebutuhan spiritual pasien di ruang rawat inap Medik-Bedah RSUD Dr. H. Chasan Boesoirie Ternate. Hal ini dapat diasumsikan bahwa semakin baik pengetahuan perawat maka sikapnya semakin positif, sebaliknya semakin kurang pengetahuan maka cenderung lebih bersikap negatif terhadap pemenuhan kebutuhan spiritual pasien.

\section{Motivasi}

Motivasi adalah kondisi atau status pikiran seseorang yang digambarkan dalam beberapa tugas khusus atau tujuan. Dengan demikian dapat dijelaskan bahwa motivasi merupakan suatu proses sikologis yang mencerminkan sikap, kebutuhan, persepsi, dan keputusan yang terjadi pada diri seseorang (Sitorus dan Panjaitan, 2011).

Penelitian Ismail pada tahun 2012, di RSKD Makassar yang menyimpulkan bahwa terdapat beberapa faktor yang mempengaruhi pelaksanaan intervensi spiritual antara lain: 1) Motivasi/kemauan; 2) Waktu yang tersedia untuk intervensi spiritual; 3) Role model spiritual dari perawat; dan 4) Usia perawat. Berdasarkan hasil penelitian ini didapatkan dari 43 perawat yang memiliki motivasi tinggi, $53,5 \%$ diantaranya memiliki sikap yang positif, sedangkan dari 52 perawat yang memiliki motivasi rendah, sebagian besar yaitu 76,9\% yang memiliki sikap negatif dalam pemenuhan kebutuhan spiritual pasien. Hal ini dapat diasumsikan bahwa perawat dengan motivasi tinggi cenderung lebih bersikap positif dalam pemenuhan kebutuhan spiritual pasien, sebaliknya perawat yang memiliki motivasi rendah lebih besar kecenderungan untuk bersikap negatif dalam memenuhi kebutuhan spiritual pasien.

Berdasarkan hasil penelitian diketahui bahwa dari 95 responden, 35 orang $(36,8 \%)$ memiliki sikap positif dan 60 orang $(63,2 \%)$ yang memiliki sikap negatif dalam pemenuhan kebutuhan spiritual pasien di ruang rawat inap Medik-Bedah RSUD Dr. H. Chasan Boesoirie Ternate. Adapun hasil kuesioner pengetahuan menunjukkan bahwa dari total 95 responden, terbanyak responden memilih jawaban yang benar pada poin 1 tentang defenisi dari spiritualitas, yaitu 90 orang $(97,7 \%)$ dan 75 orang $(78,9 \%)$ responden yang setuju dengan pernyataan sikap pada poin 1 yaitu dalam memberikan asuhan keperawatan, perawat memandang pasien secara holistik. Hal ini dapat diasumsikan bahwa perawat memahami tentang spiritualitas dimana setiap orang memiliki keyakinan dalam hubungannya dengan Tuhan, diri sendiri, dan orang lain/lingkungan, perawat juga memahami tentang tugas dan tanggung jawabnya dalam hal pemenuhan kebutuhan pasien secara holistik/ menyeluruh, akan tetapi disisi lain sebagian besar responden, 56 orang $(58,9 \%)$ setuju dengan pernyataan negatif pada poin 10 dari pernyataan sikap tentang aspek spiritual tidak berpengaruh terhadap proses penyembuhan pasien, sedangkan $50,5 \%$ - 
$58,9 \%$ responden setuju dengan poin 5 dan 7 tentang pemenuhan kebutuhan spiritual pasien adalah tanggung jawab keluarga, pemimpin agama/ rohaniawan, dan hanya 27 orang $(28,4 \%)$ yang setuju dengan pernyataan positif bahwa kebutuhan spiritual pasien adalah tanggung jawab perawat. Hal ini dapat diasumsikan bahwa sikap positif perawat sering kali ditunjukkan dengan memandang pasien secara holistik, mencakup bio-psikososial-spiritual dan kultural sebagai komponen yang utuh atau merupakan satu kesatuan yang tidak dapat dipisahkan dalam pelayanan asuhan keperawatan, sebaliknya sikap negatif perawat di ruang rawat inap Medik-Bedah RSUD Dr. H. Chasan Boesoirie Ternate bisa disebabkan karena perawat memandang pemenuhan kebutuhan spiritual pasien sebagai tanggung jawab pasien itu sendiri, keluarga atau rohaniawan semata, bahkan menganggap aspek spiritual tidak berpengaruh terhadap proses penyembuhan pasien sehingga perawat yang demikian cenderung lebih memperioritaskan pemenuhan kebutuhan biologis/fisiologis, dan baru akan mendampingi pasien ketika menghadapi sakratul maut. Hal ini sesuai dengan pernyataan Hamid tahun 2009, bahwa perawat kurang memperhatikan aspek spiritual dalam perawatan karena perawat kurang memahami tentang aspek spiritual dan manfaatnya terhadap kesehatan serta penyembuhan penyakit pasien.

Perawat merupakan orang yang pertama dan secara konsisten selama 24 jam sehari menjalin kontak dengan pasien, maka perawat sangat berperan dalam membantu memenuhi kebutuhan spiritual pasien, baik dengan mengusahakan kemudahan seperti mendatangkan pemuka agama sesuai dengan agama yang diyakini pasien, memberikan privacy untuk berdoa, atau memberi kelonggaran bagi pasien untuk berinteraksi dengan orang lain, keluarga/teman (Hamid, 2009).

Kenyataannya pemenuhan kebutuhan spiritual ini masih jauh dari yang diharapkan, karena berdasarkan pengamatan penulis selama bertugas di RSUD Dr. H. Chasan Boesoirie Ternate, khususnya di ruang rawat inap MedikBedah, kebutuhan spiritual ini seakan hanya menjadi prioritas pada pasien dalam keadaan kritis atau menjelang kematian, dan sebagian besar perawat tidak mendampingi pasien pada saat menjelang kematian/sakratul maut karena perawat sibuk melaksanakan tindakan-tindakan yang mengarah pada pengobatan pasien yaitu melakukan tindakan sesuai dengan instruksi dokter sehingga kebutuhan spiritual pasien seakan terabaikan. Berdasarkan jawaban kuesioner pernyataan sikap negatif pada poin 11 bahwa 44,2\% menjawab setuju dengan pernyataan tentang perawat lebih memperioritaskan pemenuhan kebutuhan biologis/fisiologis pasien dari pada kebutuhan yang lainnya. Menurut Wright, 2000 (dikutip dalam Hamid, 2009), mengatakan bahwa dalam memberikan asuhan keperawatan, perawat lebih cenderung memperhatikan aspek curent (pengobatan). Hal ini juga dapat disebabkan karena perawat kurang memahami tentang pentingnya aspek spiritual ketika kondisi seseorang mengalami perubahan, sebagaimana hasil kuesioner pengetahuan menunjukkan dari total 95 responden, sebanyak 42 orang $(39,9 \%)$ yang salah memberikan jawaban poin 5 tentang kondisi yang umumnya menjadi masalah spiritual pasien, dan berdasarkan hasil kuesioner pernyataan sikap pada poin 3, sebagian responden yaitu 51 orang $(53,7 \%)$ yang memberikan pernyataan setuju dan sangat setuju terhadap pernyataan negatif tentang pengkajian aspek spiritual hanya dilakukan pada pasien dengan penyakit terminal. Hal ini dapat diasumsikan bahwa $39,9 \%-53,7 \%$ perawat menganggap masalah spiritual hanya terjadi pada kodisi penyakit terminal, sehingga pemenuhan kebutuhan spiritual pada pasien penyakit akut dan kronis sering diabaikan oleh perawat di ruang rawat inap Medik-Bedah RSUD Dr. H. Chasan Boesoirie Ternate.

Salah satu aspek pelayanan profesional dalam keperawatan adalah masalah pemenuhan kebutuhan spiritual. Hal ini menjadi penting karena ketika kondisi fisik seseorang terganggu maka ada kemungkinan mengalami perubahan emosi, pada kondisi tersebut aspek spiritual seseorang sangat diperlukan untuk mengatasi perubahan emosi. Keimanan pada Tuhan diyakini akan memudahkan seseorang untuk mengatasi perubahan emosional selama sakit (Hawari, 2010). Peran perawat dalam hal ini adalah memenuhi kebutuhan spiritual pasien walaupun perawat dan pasien memiliki keyakinan/agama yang berbeda, namun kenyataan yang terjadi di ruang rawat inap Medik-Bedah RSUD Dr. H. Chasan Boesoirie Ternate, bahwa perawat kurang memahami tentang perannya dalam hal pemenuhan kebutuhan spiritual pasien, hal ini berdasarkan hasil kuesioner pengetahuan poin 4 tentang peran perawat dalam pemenuhan kebutuhan spiritual pasien, yaitu sebanyak $50,5 \%$ 
responden memberikan jawaban yang salah terhadap pertanyaan tersebut.

Hubungannya dengan peran perawat, Rando 1984 (dikutip oleh Hamid, 2009). Menyebutkan menjalin komunikasi yang terapeutik terhadap pasien yang sedang menghadapi kematian juga merupakan bagian dari pemenuhan kebutuhan spiritual pasien. Kriteria paling umum yang dikaji perawat untuk spiritualitas adalah kebiasaan ibadah dan ritual keagamaan lainnya, seperti partisipasi dalam anggota kelompok dalam doa bersama. Selama pengkajian perawat mengetahui apakah berdoa merupakan ritual penting bagi klien dan kemudian menentukan apakah intervensi dibutuhkan sehingga berdoa dapat dilakukan. Intervensi dapat mencakup membentuk privasi, mendorong kunjungan dari rohaniawan, atau berdoa bersama klien. Perawat perlu mengkaji apakah ritual atau ibadah yang dianut pasien telah terganggu akibat penyakit dan perawatan di rumah sakit (Potter \& Perry, 2008). Potter \& Perry, menyatakan bahwa jika pasien mengalami distres spiritual dan masalah kesehatan yang menyebabkan keputusasaan, maka akan timbul perasaan kesepian dan pasien merasa terisolasi dari orang yang biasanya memberi dukungan. Dengan demikian apapun keragaman intervensi yang mungkin dipilih oleh perawat untuk pasien, yang terpenting adalah hubungan saling mengasihi dan saling memahami. Baik pasien maupun perawat harus merasa bebas untuk merelakan dan menemukan bersama makna penyakit yang dialami pasien dan dampaknya pada makna dan tujuan hidup pasien. Pada tingkat pemahaman ini, perawat mampu memberikan perawatan dengan cara yang tepat, sensitif, dan kreatif.

Menurut Burkhardt, 1983 (dikutip dalam Hamid, 2009), menyatakan bahwa spiritualitas meliputi aspek: 1) Berhubungan dengan sesuatu yang tidak diketahui atau ketidakpastian dalam kehidupan, 2) Menemukan arti dan tujuan hidup, 3) Menyadari kemampuan untuk meggunakan sumber dan kekuatan dalam diri sendiri, 4) Mempunyai perasaan keterikatan dengan diri sendiri dan dengan Yang Maha Tinggi. Hasil kuesioner pengetahuan menunjukkan bahwa poin pertanyaan yang paling sedikit dijawab benar oleh responden adalah poin 2 tentang apa yang dimaksud dengan kebutuhan spiritual, dan poin 14 tentang fokus asuhan keperawatan pada pasien dengan distress spiritual yaitu masing-masing hanya 31 orang $(32,6 \%)$ yang memberikan jawaban benar terhadap pertanyaan, dengan demikian dapat diasumsikan bahwa pengetahuan perawat tentang aspek spiritual masih dipahami sebatas perasaan keterikatan antara diri sendiri dengan Yang Maha Tinggi, dan masih minimnya pengetahuan perawat tentang asuhan keperawatan pada pasien dengan distress spiritual menyebabkan perawat lebih bersikap negatif terhadap pemenuhan kebutuhan spiritual pasien. Hal ini sesuai dengan pernyataan Hamid (2010), bahwa kurangnya pengetahuan perawat tentang asuhan keperawatan spiritual pasien menjadi salah satu penyebab pemenuhan kebutuhan spiritual pasien kurang diperhatikan oleh perawat.

Sumiati, dkk. dalam penelitiannya pada tahun 2008, tentang pemahaman perawat terhadap pemenuhan kebutuhan spiritual klien pada pasien lansia di RSUD Mardi Lestari kabupaten Sragen menyebutkan bahwa kebutuhan spiritual sebagai bagian dari kebutuhan manusia secara utuh hanya dapat dipenuhi apabila perawat dibekali dengan kemampuan memberikan asuhan keperawatan dengan memperhatikan aspek spiritual klien sebagai bagian dari kebutuhan holistik pasien.

Penelitian terdahulu seperti Fryback, 1999 (dikutip dalam Potter \& Perry 2008, p.568) menyebutkan bahwa sebagian perawat merasa tidak mampu memberikan perawatan spiritual kepada pasien, dengan alasan : 1) Perawat memandang agama sebagai masalah pribadi, 2) Perawat berpikir bahwa spiritualitas merupakan masalah pribadi yang hanya merupakan hubungan individu dengan penciptanya, 3) Perawat merasa tidak nyaman dengan agama/kepercayaanya, 4) Perawat tidak tahu tentang asuhan keperawatan spiritual, 5) Perawat menjalankan kebutuhan spiritual untuk kebutuhan psikososial, dan 6)Perawat memandang bahwa pemenuhan kebutuhan spiritual pasien bukan tanggung jawabnya melainkan tanggung jawab keluarga dan tokoh agama.

Potter \& Perry berpendapat bahwa penerapan proses keperawatan dari perspektif kebutuhan spiritual pasien tidak sederhana, dan sangat jauh dari sekedar mengkaji praktik dan ritual keagamaan pasien, yang terpenting adalah bagaimana memahami spiritualitas pasien dan kemudian secara tepat mengidentifikasi tingkat dukungan dan sumber yang diperlukan. Lebih lanjut disebutkan, aspek penting dari perawatan spiritual adalah mengenali bahwa pasien tidak harus (berhak) mempunyai masalah spiritual. Pasien membawa kekuatan spiritual tertentu yang 
dapat digunakan oleh perawat sebagai sumber untuk membantu pasien agar menjalani gaya hidup yang lebih sehat, sembuh dari penyakit, atau menghadapi kematian dengan tenang. Pendapat tersebut memberi pemahaman bahwa, sikap perawat dalam memenuhi kebutuhan spiritual pasien bukan hanya ditujukan kepada pasien yang penyakitnya kritis atau penyakit terminal, namun juga pada pasien yang tidak sedang dalam menghadapi masalah spiritual. Hal ini mengindikasikan bahwa, pada dasarnya setiap perawat dituntut untuk memiliki sikap konsisten dan intervensi yang tepat dalam memenuhi kebutuhan spiritual pasien.

Menurut Taylor, Lillis \& Le Mone, 1997 ; dan Craven \& Hirnle, 1996 (dikutip oleh Hamid, 2009), salah satu faktor penting yang dapat mempengaruhi spiritualitas seseorang adalah : Asuhan keperawatan yang kurang sesuai. Ketika memberikan asuhan keperawatan, perawat diharapkan peka terhadap kebutuhan spiritual pasien, tetapi dengan berbagai alasan ada kemungkinan perawat juga menghindari untuk memberikan asuhan spiritual. Alasan tersebut antara lain: karena perawat merasa kurang nyaman dengan kehidupan spiritualnya, kurang menganggap penting kebutuhan spiritual, tidak mendapatkan pendidikan tentang aspek spiritual dalam keperawatan, atau merasa bahwa pemenuhan kebutuhan spritual pasien bukan menjadi tugasnya tetapi tanggung jawab pemuka agama.

Terkait dengan sikap tersebut, Notoatmojo (2010) menyatakan bahwa sikap menggambarkan suka atau tidak suka seseorang terhadap objek, yang sering diperoleh dari pengalaman sendiri atau melalui orang lain. Jika dikaitkan dengan sikap perawat dalam pemenuhan kebutuhan spiritual pasien di ruang rawat inap Medik-Bedah RSUD Dr. H. Chasan Boesoirie Ternate, maka dapat diasumsikan bahwa dari $60 \%$ perawat yang memiliki sikap negatif terhadap pemenuhan kebutuhan spiritual pasien di ruang rawat inap Medik-Bedah terjadi karena beberapa alasan, diantaranya: 1) Sebagian besar perawat menilai pemenuhan kebutuhan spiritual pasien bukan tanggung jawab perawat melainkan tanggung jawab pasien itu sendiri, keluarga dan tokoh agama/rohaniawan, 2) Perawat menganggap aspek spiritual tidak berpengaruh terhadap proses penyembuhan, 3 ) Perawat menganggap masalah spiritual hanya terjadi pada kodisi penyakit terminal, 4) Perawat lebih memperioritaskan aspek biologis/ fisiologis, 5) Perawat belum memahami tentang aspek spiritual dan (6) Masih minimnya pengetahuan perawat tentang asuhan keperawatan pada pasien dengan distress spiritual.

Dari keseluruhan uraian diatas, dapat disimpulkan bahwa, sikap perawat terhadap pemenuhan kebutuhan spiritual pasien belum optimal. Hal ini disebabkan oleh kurangnya pemahaman perawat mengenai arti penting dari spiritualitas, dan masih terbatasnya kemampuan SDM perawat dalam menerapkan prinsip-prinsip asuhan keperawatan spiritual.

\section{KESIMPULAN DAN SARAN}

\section{Kesimpulan}

Dari hasil penelitian ini dapat disimpulkan bahwa ada hubungan yang bermakna antara faktor pendidikan, pengetahuan dan motivasi dengan sikap perawat dalam pemenuhan kebutuhan spiritual pasien di ruang rawat inap Medik-Bedah RSUD Dr. H. Chasan Boesoirie Ternate, sedangkan faktor yang paling dominan hubungannya dengan sikap adalah pendidikan. Disamping itu sikap perawat terhadap pemenuhan kebutuhan spiritual pasien belum optimal, hal ini disebabkan karena kurangnya pemahaman perawat mengenai arti penting dari spiritualitas, dan masih terbatasnya kemampuan SDM perawat dalam menerapkan prinsip-prinsip asuhan keperawatan spiritual.

\section{Saran}

Upaya peningkatan sumber daya manusia yang terkait dengan mutu pelayanan keperawatan pada umumnya dan khususnya dalam hal pemenuhan kebutuhan spiritual pasien melalui penerapan asuhan keperawatan secara holistik harus terus dilakukan oleh pihak rumah sakit. Selain itu perawat diharapkan terus mengembangkan potensi diri melalui jenjang pendidikan tinggi keperawatan agar dapat meningkatkan pengetahuan dan sikap positif terhadap pemenuhan kebutuhan spiritual pasien.

\section{DAFTAR PUSTAKA}

Aswar S. 2009. Sikap manusia. Pustaka Belajar :Yogyakarta.

Amelianus, M. 2003, Hubungan pengetahuan dengan sikap perawat dalam pemenuhan kebutuhan spiritual klien denga krisis penyakit/penderitaan/kematian di ruang bedah dan interna RSUD Prof. DR. 
W.Z. Johannes Kupang, Skripsi tidak diterbitkan. Surabaya : Program Studi Ilmu Keperawatan Fakultas Kedokteran UNAIR SURABAYA.

Amelia, L. 2011, Relationship with religiosity meaningfulness kidney failure of life in patients in terminal RS Pau Halim, Gunadarma University, diakses tanggal 29 agustus 2012, <papers.gunadarma.ac.id./index.php/psy chology/article/view/920/876>

Asrinah, S. 2011, Pengaruh intervensi keperawatan spiritual keagamaan terhadap tingkat ansietas pasien terminal di RSUP Dr. Wahidin Sudirohusodo Makassar, Skripsi tidak diterbitkan. Makassar : Program Studi Ilmu Keperawatan Fakultas Kedokteran UNHAS MAKASSAR

Dahlan, M. S. 2011. Statistik untuk kedokteran dan kesehatan. Selemba Medika : Jakarta.

Dahlan, M. S. 2010. Langkah-langkah membuat proposal penelitian bidang kedokteran dan kesehatan. Salemba Medika: Jakarta.

Dahlan, M. S. 2010. Besar sampel dan cara pengambilan sampel dalam penelitian kedokteran dan kesehatan. Salemba Mediak: Jakarta

Darma, K. 2011. Metodologi penelitian keperawatan, panduan melaksanakan dan menerapkan hasil penelitian. Trans Info Media : Jakarta.

Hamid A.Yani. 2009. Bunga rampai asuhan keperawatan jiwa. EGC : Jakarta.

Hawari, D. 2008. Dimensi relegi dalam praktek psikiatri dan psikologi. Balai Penerbit FKUI : Jakarta

Hawari, D. (2010). Panduan psikoterapi agama Islam. Balai Penerbit FKUI: Jakarta

Ismail 2012. Hubungan tingkat pengetahuan perawat tentang perawatan spiritual dengan pelaksanaan intervensi spiritual di Rumah Sakit Khusus Daerah (RSKD) Makassar, Jurnal Media Kesehatan Kopertis Wilayah Ix Sulawesi, 23 Maret, p. 2.

Kuntoro, A. 2010. Buku ajar manajemen keperawatan. Nuha Medika : Yogyakarta.

Nursalam 2011. Manajemen keperawatan. aplikasi dalam praktik keperawatan profesional.Sagung Seto :Jakarta.

Notoatmodjo, S. 2010. Metodologi penelitian kesehatan.Bina Cipta : Jakarta
Notoatmodjo, S. 2010. Ilmu perilaku kesehatan. Rineka Cipta : Jakarta

Potter, P.A \& Perry, A.G. 2008. Buku ajar fundamental keperawatan, konsep, proses, dan praktik. Volume 1. Edisi 4. Alih Bahasa : Yasmin Asih, S.Kp, dkk. EGC : Jakarta

Purwanto M. 2008. Psikologi pendidikan. PT. Remaja Rosdakarya: Bandung.

Rahmat, I 2002, Keefektifan pemberian bimbingan spiritual Islami kepada klien terminal terhadap kecemasan dan motivasi hidup di RSU PKU Muhammadiyah Yogyakarta, Berita Kedokteran Masyarakat XVIII (4), 28 September, Vol. 18(4), p. 169-175

Sastroamoro, S. \& Ismael, S. 2008. Dasardasar metodologi penelitian klinik. Edisi ke-3Sagung Seto : Jakarta.

Siagian, S.P. 2011. Manajemen Sumber Daya Manusia. PT. Bumi Aksara. Jakarta

Sitorus, R. \& Panjaiatan, R. 2011. Manajemen keperawatan : Manajemen keperawatan di ruang rawat. Sagung Seto : Jakarta.

Sugiyono 2011. Metode penelitian kuantitatif kualitatif dan $\mathrm{R}$ \& $\mathrm{D}$. Alfabeta : Bandung.

Sumiati, T. dkk. 2010, Pemahaman perawat terhadap pemenuhan kebutuhan spiritual klien pada pasien lansia di RSUD Mardi Lestari Kabupaten Sragen, Fakultas Kedokteran Program Studi Ilmu Keperawatan UNDIP, diakses tanggal 10 mei 2012, http://empiris.undip.ac.id/10288/1/INAY AH.pdf

Wawan, A \& Dewi, M. 2010. Teori \& pengukuran pengetahuan, sikap, dan perilaku manusia. Nuha Medika : Yogyakarta.

Widayatun S. I. 2009. Ilmu perilaku.Edisi Revisi, Sagung Seto : Jakarta.

Winarsih dan Faizin, A. 2008, Hubungan tingkat pendidikan dan lama kerja perawat dengan kinerja perawat di RSUD Padang Arang Kabupaten Boyolali, Berita Ilmu Keperawatan, Vol. 1 (3), September 2008, p. 137-142. 
hubungan tingkat kepatuhan diet dan status gizi pada responden rawat jalan dispepsia di RSUD dr. H.Chasan Boesoirie Ternate.

\section{Tujuan Khusus}

a. Mengetahui tingkat kepatuhan diet responden rawat jalan dispepsia di RSUD dr. H.Chasan Boesoirie Ternate.

b. Mengetahui status gizi responden rawat jalan dispepsia di RSUD dr. H.Chasan Boesoirie Ternate.

c. Mengetahui hubungan tingkat kepatuhan dan status gizi responden rawat jalan dispepsia di RSUD dr. H.Chasan Boesoirie Ternate.

\section{Kerangka Konsep}

Berdasarkan dasar pemikiran di atas maka bagan kerangka konsep variabel yang diteliti dapat digambarkan sebagai berikut:

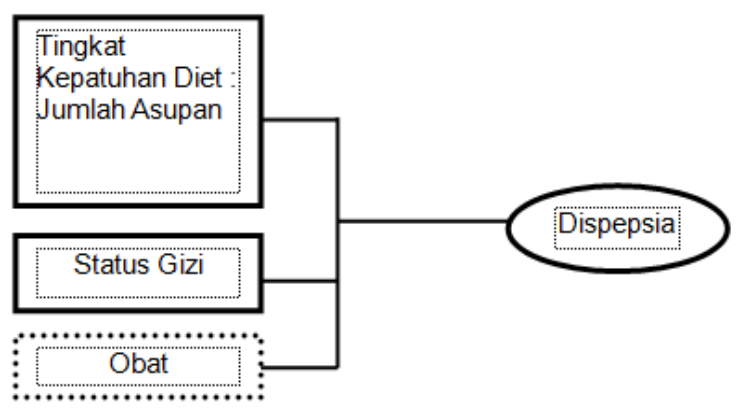

Gambar 3. Rancangan Penelitian

\section{METODE PENELITIAN}

\section{Jenis Penelitian}

Jenis penelitian yang digunakan adalah penilitian deskiptif analitik dengan pendekatan corelational untuk mempelajari dan melihat hubungan antara kepatuhan diet dengan status gizi.

\section{Tempat dan Waktu}

Penelitian ini dilakukan pada responden rawat jalan Dispepsia di RSUD dr.H.Chasan Boesoirie Ternate selama 3 bulan yaitu mulai bulan Juli sampai September 2013.

\section{Populasi dan Sampel}

Populasi dalam penelitian ini adalah semua responden rawat jalan dispepsia di RSUD. dr. H. Chasan Boesoirie Ternate.

Sampel dalam penelitian ini adalah semua responden rawat jalan dispepsia yang merupakan bagian dari populasi dengan kriteria inklusi yaitu :
1) Bersedia diwawancara

2) Usia antara 20 tahun sampai dengan 50 tahun

3) Lama menderita penyakit dispepsia 1 sampai dengan 2 tahun.

4) Memakai obat

Pengambilan sampel menggunakan metode simple random sampling. Besar sampel dalam penelitian ini diambil dengan menggunakan rumus :

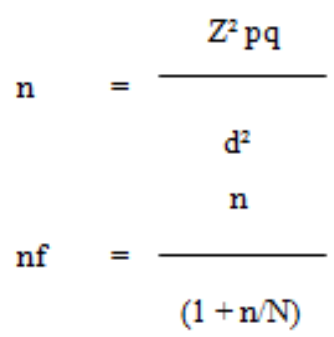

Dimana :

$$
\begin{aligned}
& \mathrm{n}=\text { besarnya sampel } \\
& \mathrm{Z}=\text { confidence of coefficient } \\
& \mathrm{p}=\text { proporsi keadaan yang bisa terjadi } \\
& \mathrm{q}=\text { proporsi keadaan yang tidak terjadi } \\
& \quad \mathrm{q}=1-\mathrm{p}
\end{aligned}
$$

\section{Jenis dan Cara Pengumpulan Data}

\section{Data Primer}

Data yang diperoleh melalui wawancara kepada responden dengan menggunakan kuesioner dan format recall 24 jam selama 3 hari dengan jarak 1 minggu sekali.

\section{Data Sekunder}

Data yang diperoleh dari bagian rekam medik RSUD Dr. H. Chasan Bosoirie yakni data jumlah responden dispepsia yang dirawat jalan.

\section{HASIL}

\section{Gambaran Umum RSUD dr. H. Chasan Boesoirie Ternate}

RSUD Dr. H. Chasan Boesoirie Ternate adalah Rumah Sakit Umum terkemuka di Maluku Utara. Namanya diambil dari nama seorang pejuang kemerdekaan Maluku Utara yakni Dr. H. Chasan Boesoirie. Beliau adalah dokter pribumi pertama yang bertugas di 
Maluku Utara dan di angkat sebagai Dokter Keresidenan.

RSUD Dr. H. Chasan Boesoirie Ternate berdiri pada tahun 1941. Tahun 1962 pemerintah kota Praja Ternate mulai membangun gedung parmanen dekade. Pada dekade tahun 1980-an RSU Ternate mulai mendapat pelayanan Dokter Spesialis yaitu Dr. Gatot Toerido Broto, Sp.B yang kemudian menjadi Direktur RSU Ternate dengan klasifikasi rumah sakit kelas D dan berada dibawah Pemerintah Kabupaten Maluku Utara.

Pada tahun 1987 bulan Oktober resmi berubah status menjadi Rumah Sakit kelas C berdasarkan SK Menkes no 303/MENKES/IV/87/IV/1987. Pada tanggal 9 Oktober diresmikan namanya RSUD Dr. H. Chasan Boesoirie Ternate, dan pada tanggal itu ditetapkan sebagai hari ulang tahun RSUD Dr. H. Chasan Boesoirie Ternate. Setahun kemudian berdasarkan Keputusan Menteri Kesehatan RI Nomor : 1476/MENKES/SK/X/2003 tanggal 24 Oktober, klasifikasi RSUD Dr. H. Chasan Boesoirie ditingkatkan dari kelas $\mathrm{C}$ menjadi kelas B non pendidikan. Saat itu telah memiliki 16 orang Dokter Spesialis, 12 orang Dokter Umum, 2 orang Dokter Gigi dengan kapasitas pelayanan 210 tempat tidur (Profil RSUD, Dr. H. Chasan Boesoirie Ternate, 2011).

\section{Karakteristik Umum Responden}

Responden yang digunakan dalam penelitian ini berjumlah 27 orang yang terdiri dari responden rawat jalan RSUD Dr. $\mathrm{H}$. Chasan Boesoirie Ternate.

Tabel 1.Distribusi Responden Berdasarkan Jenis Kelamin Pada Responden Penderita Dispepsia di RSUD. Dr. H. Chasan Boesoirie Ternate Tahun 2013

\begin{tabular}{lcl}
\multicolumn{1}{c}{ Jenis Kelamin } & n & $\mathbf{( \% )}$ \\
\hline Laki-laki & 8 & 29,6 \\
Perempuan & 19 & 70,4 \\
\hline Total & $\mathbf{2 7}$ & $\mathbf{1 0 0}$ \\
\hline Sumber : Data Primer, 2013 & &
\end{tabular}

Data pada tabel 1, menunjukkan bahwa distribusi responden penderita dispepsia berdasarkan jenis kelamin laki-laki sebanyak 8 orang $(29,6 \%)$ dan perempuan sebanyak 19 orang $(70,4 \%)$. Data tersebut menunjukan penyakit dispepsia cenderung diderita oleh perempuan dibandingkan laki-laki dalam penelitian ini.

Tabel 2. Distribusi Responden Berdasarkan Umur Responden Penderita Dispepsia di RSUD. Dr. H. Chasan Boesoirie Ternate Tahun 2013

\begin{tabular}{ccc}
\hline Umur & $\mathbf{n}$ & $\mathbf{( \% )}$ \\
\hline $21-39$ & 9 & 33,3 \\
$40-58$ & 12 & 44,4 \\
$59-74$ & 6 & 22,2 \\
\hline Total & $\mathbf{2 7}$ & $\mathbf{1 0 0}$ \\
\hline
\end{tabular}

Sumber : Data Primer, 2013

Data pada tabel 2, menunjukan sebaran umur responden penderita dispepsia bervariasi dimana kisaran umur 40-58 tahun sebanyak 12 orang (44,4\%), umur 21-39 tahun sebanyak 9 orang $(33,3 \%)$ dan responden dengan kisaran umur 59-74 tahun berjumlah 6 orang (22.2\%). Data tersebut menggambarkan responden penderita dispepsia kecenderung terjadi pada usia 40-58 tahun dalam penelitian ini.
Dari tabel 4 di bawah ini, menunjukkan bahwa responden penderita dispepsia berdasarkan tingkat pendidikan SMA sebanyak 9 orang $(33,3 \%)$ dan pendidikan S1 sebanyak 8 orang $(29,6 \%)$, sedangkan responden dengan tingkat pendidikan SD Sebanyak 4 orang $(14,8 \%)$, SMP Sebanyak 2 orang $(7,4, \%)$ dan pendidikan S2 dan S3 masing-masing yaitu 1 orang $(3,7 \%)$.

Tabel 3. Distribusi Responden Berdasarkan Pendidikan Pada Responden Dispepsia di RSUD. Dr. H. Chasan Boesoirie Ternate Tahun 2013 


\begin{tabular}{lcc}
\hline \multicolumn{1}{r}{ Pendidikan } & n & $(\boldsymbol{\%})$ \\
\hline SD & 4 & 14,8 \\
SMP & 2 & 7,4 \\
SMA & 9 & 33,3 \\
Akademi & 2 & 7,4 \\
S1 & 8 & 29,6 \\
S2 & 1 & 3,7 \\
S3 & 1 & 3,7 \\
\hline Total & $\mathbf{2 7}$ & $\mathbf{1 0 0}$ \\
\hline
\end{tabular}

Sumber : Data Primer, 2013

Data pada tabel 3. menunjukan bahwa kepatuhan diet pada responden penderia dispepsia tidak menerapkan diet yang dianjurkan secar benar dalam pola makan sehari-hari, karena asupan makanan yang dimakan terutama sumber protein lemak dan karbohidrat diatas standar kebutuhan yang dianjurkan yaitu $90-110 \%$. Nilai rasio asupan kebutuhan minimum adalah $95 \%$ dari asupan makanan dan maksimum $460 \%$ dari asupan makanan dengan rasio asupan kebutuhan ratarata $231,44 \pm 88,01 \mathrm{SD}$.

Hasil analisis juga ditemukan nilai indek masa tubuh (IMT) responden penderita dispepsia sangat bervariasi. Nilai indeks masa tubuh (IMT) minimum adalah 17 dan maksimum adalah 29 dengan indek masa tubuh (IMT) 23,85 $\pm 3,57 \mathrm{SD}$. Nilai IMT bila dibandingkan dengan standar baku antropometri Depkes 2003 (tabel 6), maka terdapat sebagian responden dengan status gizi normal, gemuk dan obesitas. Terjadi variasi status gizi (IMT) karena hasil pengukuran berat badan rata-rata responden penderita dispepsia $57,56 \mathrm{~kg} \pm 8,31$ dan tinggi badan ratatata $155,19 \mathrm{~cm} \pm 5,92 \mathrm{SD}$

Tabel 4. Gambaran Deskriptif Kepatuhan Diet, Berat Badan, Tinggi Badan dan Status Gizi

Berdasarkan Indeks Masa Tubuh Responden Penderita Dispepsia di RSUD. Dr. H. Chasan Boesoirie Ternate Tahun 2013

\begin{tabular}{lccr}
\hline \multicolumn{1}{c}{ Variabel diteliti } & Minimum & Maximum & \multicolumn{1}{c}{ Mean\$SD } \\
\hline Kepatuhan diet & 92 & 466 & $231,44 \$ 88,01$ \\
Berat Badan & 40 & 75 & $57,56 \$ 8,31$ \\
Tinggi badan & 149 & 165 & $155,19 \$ 5,92$ \\
Indek Masa Tubuh & 17 & 29 & $23,85 \$ 3,57$ \\
\hline
\end{tabular}

Sumber : Data Primer, 2013

Data pada tabel 4. menunjukan nilai IMT berdasarkan standar Depkes 2003 dalam Cornelia et al (2010), bahwa sebagian besar responden penderita dispepsia berstatus gizi normal sebanyak 15 orang $(55,6 \%)$ dengan nilai kisaran IMT 18,5-25,0.
Sedangkan reponden dispepsia berstatus gizi gemuk sebanyak 8 orang $(29,6 \%)$ dengan nilai kisaran IMT 25,1-27,0 dan berstatus gizi obesitas sebayak 4 orang $(14,8 \%)$ dengan nilai kisaran IMT > 27,0.

Tabel 5. Gambaran Status Gizi (IMT) Berdasarkan Standar Depkes 2003 Pada Responden Penderita Dispepsia di RSUD. Dr. H. Chasan Boesoirie Ternate Tahun 2013

\begin{tabular}{|c|c|c|}
\hline Nilai IMT & & $\%$ \\
\hline$<17,0$ & 0 & 0 \\
\hline $17,0-18,4$ & 0 & 0 \\
\hline $18,5-25,0$ & 15 & 55,6 \\
\hline $25,1-27,0$ & 8 & 29,6 \\
\hline$>27,0$ & 4 & 14,8 \\
\hline Total & 27 & 100 \\
\hline
\end{tabular}

Sumber : Data Primer, 2013 
Tabel 6. Hubungan Kepatuhan Diet Dengan Status Gizi (IMT) pada Responden Penderita Dispepsia di RSUD. Dr. H. Chasan Boesoirie Ternate Tahun 2013

\begin{tabular}{|c|c|c|}
\hline $\begin{array}{l}\text { Pearson } \\
\text { Correlation }\end{array}$ & Staus gizi (IMT) & $\alpha$ \\
\hline Kepatuhan diet & 0,518 & $0,001<0,5$ \\
\hline
\end{tabular}

Sumber : Data Primer, 2013

Data pada tabel 6, menunjukan hasil anasilis statistik correlation product moment antara kepatuhan diet dengan satus gizi (IMT) memiliki hubungan yang kuat dan positif.

Nilai $r$ hit $0,518>r_{\text {tabel }} 0,381$ yang singnifikan pada taraf $0,001<0,5$ dengan tingkat kepercayaan 95\%. Hasil ini menunjukan bahwa kepatuhan diet memiliki hubungan yang kuat terhadap dispepsia. Konsumsi makanan dalam prorsi besar dan tidak teratur sebagai faktor pemicu terjadinya dispepsia.

\section{PEMBAHASAN}

Dispepsia merupakan kumpulan gejala yang terdiri dari nyeri ulu hati, mual, kembung, muntah, rasa penuh atau kenyang. Masalah Dispepsia merupakan masalah yang sering ditemukan dalam kehidupan sehari-hari . Keluhan ini sangat bervariasi baik dalam bentuk gejala yang ada maupun gejala dari waktu ke waktu. (Djojoningrat, 2001). Data pada (tabel 7) menunjukan hasil anasilis statistik correlation product moment antara kepatuhan diet dengan satus gizi (IMT) memiliki hubungan yang kuat dan positif dimana nilai rhit $0,518>$ rtabel 0,38 yang singnifikan pada taraf $0,001<0,5$ dengan tingkat kepercayaan 95\%.

Ketidakpatuhan diet responden penderita dispepsia tentang anjuran ahli gizi dalam pengaturan jumlah porsi makanan yang dimakan berdampak terhadap status gizi. Hasil analisis data pada (tabel 5), status gizi dengan nilai indek masa tubuh (IMT) responden penderia dispepsia rata-rata yaitu $23,85 \pm 3,57 \mathrm{SD}$. Status gizi berdasarkan nilai indek masa tubuh (IMT) tersebut bila dibadingkan dengan standar Depkes 2003, maka terdapat responden penderita dispepsia berstatus gizi normal sebanyak 15 orang $(55,6 \%)$ dengan nilai kisaran IMT 18,5-25,0. Analisis juga ditemukan reponden penderita dispepsia berstatus gizi gemuk sebanyak 8 orang $(29,6 \%)$ dengan nilai kisaran IMT 25,1-
27,0 dan responden penderita dispepsia berstatus gizi obesitas sebayak 4 orang $(14,8 \%)$ dengan nilai kisaran IMT >27,0.

Status gizi lebih diduga karena tidak taat dalam pengaturan pola makan dan jumlah porsi yang tidak teratur. Dari 27 responden tingkat asupan makanan terutama zat gizi protein, lemak dan karbohidrat diatas 90-110\% asupan kebutuhan yang dianjurkan. Asupan makan yang melebih kebutuhan menyebabkan terjadi penyimpanan cadangan makanan dalam tubuh dalam bentuk lemak tubuh, glikogen otot dan dalam hati sehingga berdampak terhadap status gizi lebih yang dialami dan proses penyebuhannya (Almatsier, 2005).

Penelitian yang dilakukan Ervianti dalam Andre Yuriko et al, (2013) tentang faktor yang berhubungan dengan kejadian sindroma dispepsia, didapatkan bahwa terdapat hubungan kejadian sindroma dispepsia dengan frekuensi dan jumlah makanan. Hasil penelitian Sukariadi et al (2013), di Rumah sakit RSUD Lasinrang Pinrang diperoleh hasil bahwa terdapat hubungan yang signifikan antara pola makan, asupan makanan dengan kejadian dispepsia.

Memiliki kebiasaan makan yang buruk, tergesa-gesa dalam jumlah yang bayak, dan jadwal yang tidak teratur dapat memperlambat proses penyembuhan penderia dispepsia (Andre Yuriko et al, 2012). Makan secara teratur dan menerapkan makan lebih dari dua kali per hari dalam porsi kecil lebih baik untuk membantu lambung beradaptasi sehingga sekresi asam lambung terkontrol dibadingkan makan makanan dalam jumlah yang banyak (Fema.IPB.ac.id 2011). Pola makan yang tidak teratur pada responden penderita dispepsia akan memperlambat proses penyembuhan penyakitnya

\section{KESIMPULAN DAN SARAN}

\section{Kesimpulan}

1. (100\%) responden penderia dispepsia tidak patuh terhadap diet yang dianjurkan. 
2. Sebagian besar responden penderia dispepsia memiliki satus gizi normal berdasarkan (IMT) $(55,6 \%)$.

3. Terdapat hubungan yang signifikan antara kepatuhan diet dan status gizi dengan nilai rhit $0,518>$ rtabel 0,38 singnifikan pada taraf $0,001<0,5$.

\section{Saran}

1. Perlu dilakukan perbaikan pola makan dan pengaturan jumlah makanan yang dimakan oleh penderita dispepsia.

2. Melakukan penelitian lanjutan dengan mengkaji variabel kebiasaan konsumsi alkohol, merokok dan minuman berkarbonat pada kelompok jenis kelami laki-laki yang menderita dispepsia.

\section{DAFTAR PUSTAKA}

Almatsier S.2009, Prinsip Dasar Ilmu Gizi. PT. Gramedia Pustaka Utama Jakarta.

Andre Yuriko et al. 2013. Hubungan Pola Makan dengan Kejadian Depresi pada Penderita Dispepsia Fungsional. Artikel penelitian Jurnal Kesehatan Andalas. http://jurnal.fk.unand.ac.id (akses tanggal 01 September 2013).

Arisman,2004. Gizi Dalam Daur Kehidupan. EGC. Jakarta.

Center for Obesity Research and_Education, 2007.

Kategori

IMT. (online),(http:www.temple.edu/medicine /depertemens_centers/research/Center_f or_Obesity_ stafflist.htm) diakses 17 juli 2011.

Cornelia et al. 2010. Penuntun Konseling Gizi. Persatuan Ahli Gizi Indonesia (PERSAGI). PT Abdi. Jakarta

IPB. FEMA. 2011. Faktor Risiko Dispepsia Pada Mahasiswa Institut Pertanian Bogor (IPB) Abstarak. Http://fema.ipb.ac.id .(akses tanggal 01 September 2013).

Mansjoer, dkk, 2000. Kapita Selekta Kedokteran, edisi 3. Medika Aeusculapius. Jakarta

Mustafa Annasari, 2010. Ilmu Gizi Dalam Daur Kehidupan dan Diet Berbagai
Penyakit. Poltekkes RS. Dr. Soepraoen. Malang.

Nanik 2012. "Hubungan Konsumsi Zat Gizi Makro dengan Lama Hari Rawat Responden Dispepsia di Ruang Penyakit Dalam Rumah Sakit Umum Daerah (RSUD) dr. H. Chasan Boesoirie Kota Ternate tahun 2012

Riwidikdo, Handoko. 2010. Statistik Kesehatan. Mitra Cendikia Press. Jogjakarta.

Sukariadi et al (2013). Gambaran faktor-faktor yang berhubungan dengan kejadian dispepsia di bagian penyakit dalam RSUD Lasinrang Pinrang. Kategori: Vol. III No. 5 (Abstrak ) www. Poltekes makassar ac.id (akses tanggal 01 September 2013).

Syakira, Ghana. 2009. Konsep Kepatuhan Diet. http:// syakirablogspot.com/2009/01/Konsep. Kepatuhan. Html_diakses tanggal 22 April 2010).

Yuliarti, N, 2009. Maag: Kenali, Hindari, dan Obati. Andi Offset. Yogyakarta. 